\title{
COMPARISON OF SPERM PARAMETERS AND TESTIS HISTOLOGICAL STRUCTURE IN LAKE FROG (PELOPHYLAX RIDIBUNDUS) FROM AREAS WITH DIFFERENT LEVEL OF ANTHROPOGENIC POLLUTION
}

\author{
Iryna Sluchyk, Bohdan Grytsulyak, Oksana Glodan, Iryna Ivasiuk, Alexandra Khallo
}

\begin{abstract}
The aim. The aim of the work was to study the indicators of spermatogenesis in the lake frog, Pelophylax ridibundus (Pallas, 1771), in the zone of the influence of emissions from the Burshtyn Thermal Power Plant (TPP).

Materials and methods. Urinal sperm and testes samples were taken from male frogs under conditions of anthropogenic pollution (Burshtyn industrial area). Such parameters as sperm concentration in ejaculate, the number of live spermatozoa, total amount of actively mobile forms, and percentage of spermatozoa with progressive motion were determined by calculations in the hemocytometer. Testis samples were processed for routine histological method. The diameter of seminiferous tubules and histological abnormalities were studied.

Results. Studies have revealed that near the Burshtyn TPP industrial site, the sperm concentration in the sperm sample and the total number of motile spermatozoa of the lake frogs significantly decreased. The number of dead spermatozoa increases. Amphibians from polluted sites had histological abnormalities in testes such as dilation of the seminiferous tubules with sparse sperm. At the same time, the diameter of the seminiferous tubules in the animals from polluted site significantly decreased.

Conclusions. The impact of the emissions from the Burshtyn thermal power plant has an expressive reprotoxic effect that is manifested by depressive changes in testes tissue and gametes. The reproductive system of the lake frog is quite sensitive to environmental pollution. Sperm parameters and histological changes in testes are informative biomarkers and can be used for bioindication of technogenically transformed territories
\end{abstract}

Keywords: amphibians, sperm parameters, testes, histological changes, spermatogenesis, anthropogenic pollution, bioindication

How to Cite:

Sluchyk, I., Grytsulyak, B., Glodan, O., Ivasiuk, I., Khallo, A. (2021). Comparison of sperm parameters and testis histological structure in lake frog (Pelophylax ridibundus) from areas with different level of anthropogenic pollution. ScienceRise: Biological Science, 1 (26), 10-13. doi: http://doi.org/10.15587/25198025.2021 .228082

(C) The Author(s) 2021

This is an open access article under the CC BY license (http://creativecommons.org/licenses/by/4.0).

\section{Introduction}

The negative effect of adverse environmental factors on spermatogenesis is well known. Many researchers believe that anthropogenic pollutants are the main cause of the decline in fertility and premature aging of the male reproductive system in recent decades. Male subfertility is the cause of childlessness in 36-61\% of infertile marriages $[1,2]$. However, every year the spectrum of xenobiotics expands and the amount of pollutants released into the environment increases. Therefore, the priority task is monitoring of environmental pollution with reproductive toxicants and the search for informative biomarkers for their bioindication.

The most powerful fuel and energy enterprise in the western region of Ukraine is the Burshtyn Thermal Power Plant (TPP). Burshtyn TPP of "DTEK Westenergo" is located on the lands of the village Bovshiv of Halych district of Ivano-Frankivsk region near Burshtyn city and is the main environmental polluter in the Carpathian region. According to the ecological passport of the Ivano-Frankivsk region, Burshtyn TPP emits more than
180 thousand tons of pollutants into the atmosphere annually. Adequate assessment of anthropogenic impact on the environment and human health is possible only under the combination of classical physical and chemical methods and bioindication. Bioindication research is a necessary component of the Burshtyn industrial area comprehensive survey.

\section{Literary review}

Atmospheric pollution in the areas of energy industry complexes is caused by intense gas-smoke emissions of organic fuel combustion products. Emissions include substances that are endocrine disruptors, as well as other reprotoxicants. There is soil and grass pollution with $\mathrm{Hg}, \mathrm{As}, \mathrm{Pb}, \mathrm{Zn}, \mathrm{Cu}$ at different distance from Burshtyn TPP. Their Clarke concentration ranges from 1 to 7, sometimes exceeding the MPC several times [3, 4]. Male reproductive health disorders, specifically sperm count and decrease in testosterone, is correlated with an increase in a variety of endocrine disrupting chemicals. Getting into the body endocrine disruptors cause hor- 
mone-like effects, violate the homeostatic mechanisms of regulation by endogenous hormones, including reproductive function of the sexual glands $[5,6]$.

Lake frog ( $P$. ridibundus Pallas), 1771, which belongs to Pelophylax esculentus complex (Linnaeus, 1758), have been studied the most. These amphibians possess a number of qualities that are advantageous for bioindication research. $P$. ridibundus is a widely spread species that inhabits extensive areas, including anthropogenically polluted where other amphibian species are unable to survive. However, tailless amphibians are susceptible to exposure to endocrinedisrupting compounds such as heavy metals [7, 8], pesticides [9], bisphenols [10], and others, which can enter through their highly permeable skin. Therefore, green frogs could be used for assessing environmental contamination by endocrine disruptors and their influence on male reproductive function.

\section{Research aim and tasks}

The present work aimed to study lake frog, dwelling in zone of the influence Burshtyn TPP with a focus on semen and testis parameters that could potentially be developed as biomarkers of endocrine disruptors intoxication. were set:

To achieve the aim, the following objectives

1. To examine sperm cell parameters in $P$. ridibundus dwelling the different functional ecotopes of the Burshtyn industrial area.

2. To determine histological changes in testes of $P$. ridibundus from polluted and unpolluted sites.

\section{Materials and methods}

\section{1. Animals and experimental conditions}

Lake frog were collected in spawning ponds near Burshtyn (Ivano-Frankivsk region, Ukraine) individual buildings zone (II), Burshtyn TPP industrial site (III), and village Krylos (I), relatively ecologically clean area similar in natural and climatic conditions (control group). The animals were captured in May-June 2018 during the spawning season and divided by gender. For the study, sexually mature males $(n=49$, mean snout to vent length $>60.0 \mathrm{~mm}$, mean weight $20-45 \mathrm{~g}$ were taken.

\section{2. Examination of semen}

Frogs were injected intraperitoneally with surfagon (synthetic analogue of the hypothalamic gonadotropin-releasing hormone, were purchased from MosAgroGen, (Russia)) at a concentration of $1.2 \mu \mathrm{g} / \mathrm{g}$ ща body weight. Such parameters as: spermatozoa concentration in sperm sample; the total amount of actively mobile forms and the percentage of spermatozoa with progressive motion was determined by calculations in the hemocytometer under a light microscope at $\times 400$. The number of live spermatozoa was determined by staining for Bloom [11]. After examination animals were returned back to their natural habitat.

The statistical processing of the research results was conducted by the standard software product Microsoft Excel and Biostat 5.0. Data are presented as means \pm S.E.M. The probability of the difference between the comparative indicators was determined by Student's test.

\section{3. Histological examination of testes}

Testis samples from control and test frog were fixed in $10 \%$ neutral-buffered formalin, and then the samples were processed for routine wax histological evaluation (dehydrated and embedded in paraffin). Sections of $5 \mu \mathrm{m}$ were taken and stained with hematoxylin and eosin. Balsam embedded testis tissue specimens were examined under a light microscope.

All manipulations, involving the animals, were carried out under narcosis in accordance with the EU Directive 2010/63/EU for animal experiments and permission of the Ministry of Education and Science of Ukraine.

\section{Research results}

Lower sperm counts and altered sperm parameters were found in lake frogs under conditions of anthropogenic pollution. Although the average body weight of amphibians from the studied areas did not significantly differ from the control, however, the weight of the testes, as well as its relation to body weight and the volume of ejaculate demonstrated a tendency to decrease in proportion to the gradient of technogenic press (Table 1).

Table 1

Sperm parameters and characteristics of generative activity of lake frog testes in the area of influence of Burshtyn thermal power plant

\begin{tabular}{|l|c|c|c|}
\hline \multicolumn{1}{|c|}{ Parameter } & \multicolumn{3}{c|}{ Sampling site } \\
\cline { 2 - 4 } & I & II & III \\
\hline Testis weight, g & $0.41 \pm 0.04$ & $0.36 \pm 0.06$ & $0.35 \pm 0.03$ \\
\hline Relation of testis weight to total body weight, \% & $0.90 \pm 0.01$ & $0.80 \pm 0.05$ & $0.72 \pm 0.03^{*}$ \\
\hline Diameter of seminiferous tubules, $\mu \mathrm{m}$ & $284.98 \pm 8.62$ & $251.33 \pm 8.46$ & $239.53 \pm 9.21^{*}$ \\
\hline Volume of semen, ml & $0.61 \pm 2.11$ & $0.42 \pm 2.09$ & $0.39 \pm 3.12$ \\
\hline Spermatozoa concentration $\left(\times 10^{6} / \mathrm{ml}\right)$ & $140.20 \pm 5.01$ & $59.6 \pm 3.20^{*}$ & $42.7 \pm 3.14^{*}$ \\
\hline Amount of dead spermatozoa, \% & $9.53 \pm 2.05$ & $25.69 \pm 3.70^{*}$ & $31.20 \pm 1.06^{*}$ \\
\hline Total sperm motility, \% & $89.50 \pm 4.30$ & $76.32 \pm 5.03$ & $67.12 \pm 1.17^{*}$ \\
\hline Progressive sperm motility, \% & $62.30 \pm 4.20$ & $47.30 \pm 3.02^{*}$ & $48.47 \pm 5.08$ \\
\hline
\end{tabular}

Note: data are presented as means \pm S.E.M, $n=7-10 ; *$ - significantly different from the control group with $p<0.05$ 
Near the individual building of the city and the industrial site of the thermal power plant the sperm concentration in the sperm sample decreases significantly by 2.4 and 3.3 times compared to control. The number of dead spermatozoa increases to $25.69 \%$ and $31.20 \%$, respectively, but the number of living forms decreases. Investigating the kinesisgram revealed that in the control group there were $62.30 \%$ of spermatozoa with rapid progressive movement, $27.2 \%$ of spermatozoa were characterized by non-progressive movement, and $10.5 \%$ of spermatozoa were immobile. Under technogenic press, the total number of motile spermatozoa is significantly reduced to $67.12 \%$, including spermatozoa with progressive movement to $47.30 \%$.

Testes with normal histomorphology were found in the control group. The vast majority of seminiferous tubules are accurately arranged and are full of spermatocyte I, spermatocyte II, and spermatids (Fig. 1).

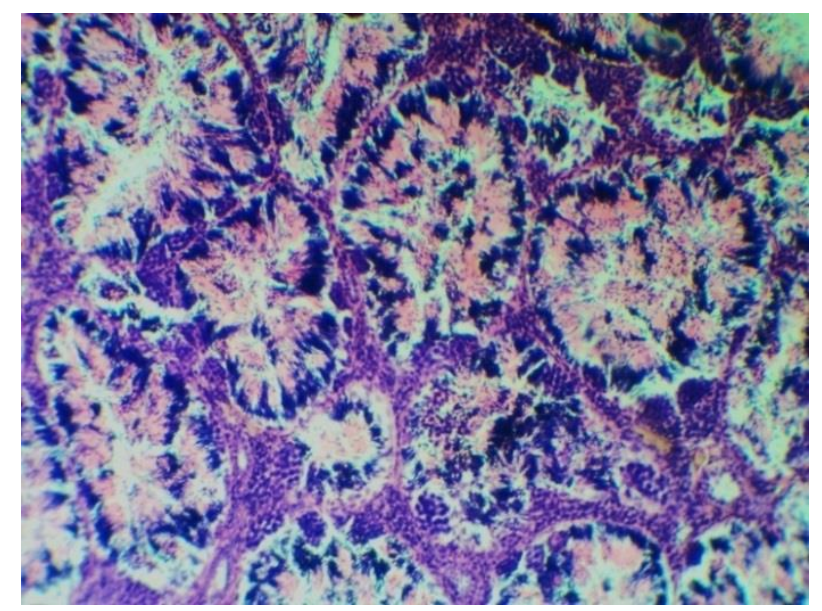

Fig. 1. Histological sections of testes of $P$. ridibundus captured in Krylos. No alterations are observed in the seminiferous tubules and interstitial tissue. Hematoxyline-eosine staining, $\times 200$

Histological examination of testis tissue specimens from industrial site showed that amphibians exposure to pollutants induced appearance of morphological changes in the organ. Tendency to increase the area of interstitial tissue (1.5-fold as compared to the control site) and decrease the area of the seminiferous tubules were registered in the zone of impact of power plant emissions.. Though the diameter of the seminiferous tubules in the vast majority of animals in the Burshtyn individual buildings zone and near the Burshtyn TPP industrial site proved to be decreased as compared to the control ones and was equal to $251.33 \pm 8.46 \mu \mathrm{m}$, and $239.53 \pm 9.21 \mu \mathrm{m}$, respectively (Table 1), at the same time we observed two males (sampling site III) with histological abnormalities manifested in presence irregularly enlarged tubules (Fig. 2).

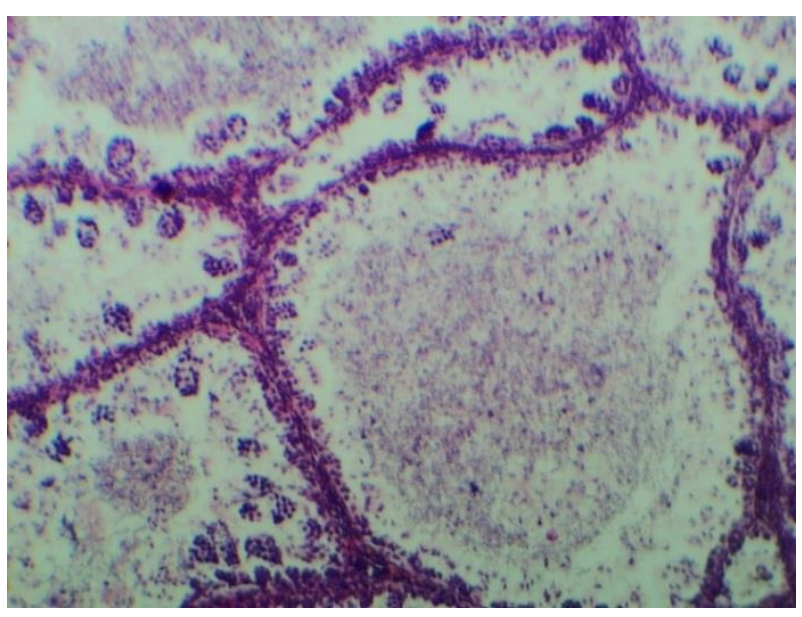

Fig. 2. Histological sections of testes of P. ridibundus captured near Burshtyn TPP industrial site. There is dilation of the seminiferous tubules, atrophy of the germ cell pool and decreased number of sperm. Hematoxylineeosine staining, $\times 200$

\section{Discussion of research results}

Decrease of seminiferous epithelium activity along with lower sperm count and sperm quality lead to reproductive ability decline. The results of our research agrees well with literature reports. There are many studies showing that almost all representatives of vertebrates from anthropogenically altered biocenoses have reactive processes in the reproductive system. There is a complex of regular nonspecific changes in the gonads: increase in the area of interstitial tissue, decrease in the diameter of the seminiferous tubules [7, 12]. Severe pollution of ecosystems causes increase in the number of tubules with different degree of damage, destructive changes in the spermatogenic epithelium [9].

The disruption of spermatogenesis in amphibian decreased the total sperm count and increase the abnormal sperm count. At the same time, males from polluted areas had more spermatozoa with pathological changes of the head, the main and intermediate parts of the flagellum. This can have a negative effect on the penetrating ability of the sperm to the egg. Pathology of the flagella impairs their motor activity. Reduced sperm motility can lead to asthenospermia and cause infertility.

Sperm motility depends on a large variety of factors, including environmental factors, and has complex mechanisms of regulation. A well-known effect of ecotoxicants is the formation and accumulation of reactive oxygen species and the activation of free radical peroxidation in the testis. According to some studies, exposure to heavy metals ( $\mathrm{Al}$, $\mathrm{Cr}, \mathrm{Cd}, \mathrm{Pb}, \mathrm{Fe}$ ) increases the number of prooxidants and has a negative effect on the functional ability and sperm motility [13], whereas the effect of $\mathrm{Zn}, \mathrm{Mg}$, and Ca protect against oxidative stress [14, 15].

Study limitation. It should be noted that this study was limited to the spring-early summer period when there is a spawning season for amphibians; the testes enlarge and begin to actively produce sperm. 
Perspectives for further research. The most significant aspect of studying the effect of xenobiotics on living organisms is the establishment of the longterm consequences of the action of their minimum doses, primarily on the fertile potential. The findings of this study motivate to develop a research line covering larger areas for long-term observation and involving possibly other amphibian species with a combination of research methods.

\section{Conclusions}

1. Near the Burshtyn TPP industrial site, the sperm concentration in the sperm sample and the total number of motile spermatozoa of the lake frogs signif- icantly decreases. The number of dead spermatozoa increases.

2. Amphibians from polluted sites had histological abnormalities in testes such as dilation of the seminiferous tubules with sparse sperm. At the same time, the diameter of the seminiferous tubules in the animals from the Burshtyn TPP industrial site significantly decreased. Thus, the results of this study indicate the emissions from the Burshtyn TPP have an expressive reprotoxic effect that is manifested by depressive changes in testes tissue and gametes.

\section{Conflict of interests.}

The authors declare that they have no conflicts of interest.

\section{References}

1. Mima, M., Greenwald, D., Ohlander, S. (2018). Environmental Toxins and Male Fertility. Current Urology Reports, 19 (7), 49-57. doi: http://doi.org/10.1007/s11934-018-0804-1

2. Reznikov, A. G. (2014). The view of a pathophysiologist-endocrinologist on the problem of age-related androgen deficiency in men (LOH syndrome). International Journal of Endocrinology, 6 (62), 11-18.

3. Pankivskyi, Y. I., Oshurkevych-Pankivska, O. Y., Ostashuk, M. B. (2017). Assessment of burshtyn TPP impact on ambient air. Scientific Bulletin of UNFU, 27 (5), 59-62. doi: http://doi.org/10.15421/40270512

4. Koshlak, N. V. (2019). Environmental hazard of the technogenic soil pollution with heavy metals for the impact areas of Burshtyn TPP. Naukovo-tekhnichnyi zhurnal, 2 (20), 7-14.

5. Yaglova, N. V., Yaglov, V. V. (2012). Endocrine disruptors are a novel direction of endocrinologic scientific investigation. Annals of the Russian Academy of Medical Sciences, 67 (3), 56-61. doi: http://doi.org/10.15690/vramn.v67i3.186

6. Rehman, S., Usman, Z., Rehman, S., AlDraihem, M., Rehman, N., Rehman, I., Ahmad, G. (2018). Endocrine disrupting chemicals and impact on male reproductive health. Translational Andrology and Urology, 7 (3), 490-503. doi: http://doi.org/10.21037/tau.2018.05.17

7. Filatova, L. N. (2011). Structure morfofunktsionalnoj of characteristic seed plant of the nimble lizard and lake frog in the zone of influence of the enterprises of ferrous meta. Vestnik OGU, 16 (135), 225-226.

8. Cao, H., Shi, C., Jia, X. (2012). Toxicity mechanism of Cadmium-induced reactive oxygen species and protein oxidation in testes of the frog Rana nigromaculata. Acta Ecologica Sinica, 32 (13), 4199-4206. doi: http://doi.org/10.5846/stxb201106020739

9. Larenas, J., Jaque, M., Bustos-López, C., Robles, C., Lobos, G., Mattar, C., Valdovinos, C. E. (2014). Histopathological findings in Gonads of Xenopus laevis from Central Chile. Gayana (Concepción), 78 (1), 70-73. doi: http://doi.org/10.4067/s071765382014000100009

10. Zhang, H., Liu, W., Chen, B., He, J., Chen, F., Shan, X. et. al. (2018). Differences in reproductive toxicity of TBBPA and TCBPA exposure in male Rana nigromaculata. Environmental Pollution, 243, 394-403. doi: http://doi.org/10.1016/j.envpol. 2018.08. 086

11. World Health Organization (2010). WHO laboratory manual for the examination and processing of human semen. Cambridge: Cambridge University Press, 4-33.

12. Shevliuk, N. N., Blinova, E. E., Bokov, D. A., Demina, L. L. (2008). Morfofunktsionalnaia kharakteristika organov razmnozheniia gryzunov iz populiatsii, nakhodiaschikhsia $\mathrm{v}$ zone vliianiia zavoda, pererabatyvaiuschego gaz $\mathrm{s}$ povyshennym soderzhaniem soedinenii sery. Morfologiia, 5, 43-47.

13. Pizent, A., Tariba, B., Zivkovic, T. (2012). Reproductive toxicity of metals in men. Archives of Industrial Hygiene and Toxicology, 63, 35-46. doi: http://doi.org/10.2478/10004-1254-63-2012-2151

14. Aloyan, K. A., Matveyev, A. V., Morev, V. V., Korneyev, I. A. (2013). Physiology of sperm motility. Urologicheskie Vedomosti, 3 (4), 14-19. doi: http://doi.org/10.17816/uroved3414-19

15. Moreno, R. D., Reyes, J. G., Farías, J. G., Parada-Bustamante, A., Aguirre, V., Zepeda, A. B. et. al. (2012). Spermatogenesis at the extreme: Oxidative stress as a converging mechanism of testicular damage due to pathological and environmental exposure. Testis: Anatomy, Physiology and Pathology. New York: Nova Science, 1-24.

Received date 21.01.2021

Accepted date 23.02.2021

Published date 31.03.2021

Iryna Sluchyk, PhD, Associate Professor, Department of Human and Animal Anatomy and Physiology, Vasyl Stefanyk Precarpathian National University, Shevchenko str., 57, Ivano-Frankivsk, Ukraine, 76018,

E-mail: iryna.sluchyk@pnu.edu.ua

Bohdan Grytsulyak, MD, Professor, Department of Human and Animal Anatomy and Physiology, Vasyl Stefanyk Precarpathian National University, Shevchenko str., 57, Ivano-Frankivsk, Ukraine, 76018

E-mail: bohdan.grytsuliak@pnu.edu.ua

Oksana Glodan, PhD, Associate Professor, Department of Human and Animal Anatomy and Physiology, Vasyl Stefanyk Precarpathian National University, Shevchenko str., 57, Ivano-Frankivsk, Ukraine, 76018

E-mail: glodan.oksana@gmail.com

Iryna Ivasiuk, PhD, Associate Professor, Department of Human and Animal Anatomy and Physiology, Vasyl Stefanyk Precarpathian National University, Shevchenko str., 57, Ivano-Frankivsk, Ukraine, 76018 E-mail: iryna.ivasiuk@pnu.edu.ua

Alexandra Khallo, PhD, Associate Professor, Department of Human and Animal Anatomy and Physiology, Vasyl Stefanyk Precarpathian National University, Shevchenko str., 57, Ivano-Frankivsk, Ukraine, 76018

E-mail: okhallo@ifnmu.edu.ua 